\title{
Association of household income with home-based rehabilitation and home help service utilization among long-term home care service users
}

Rumiko Tsuchiya-Ito ${ }^{1,2^{*}}$ (D), Tatsuro Ishizaki ${ }^{1}$, Seigo Mitsutake ${ }^{1}$, Shota Hamada ${ }^{3,4}$, Satoru Yoshie ${ }^{3,4,5,6,7}$, Katsuya lijima ${ }^{5,7}$ and Nanako Tamiya ${ }^{4,8}$

\begin{abstract}
Background: To examine the association of household income with home-based rehabilitation and home help services in terms of service utilization and expenditures.

Methods: A secondary data analysis of cross-sectional design was conducted using long-term care (LTC) insurance claims data, medical claims data, and three types of administrative data. The subjects comprised LTC insurance beneficiaries in Kashiwa city, Japan, who used long-term home care services in the month following care needs certification. Household income was the independent variable of interest, and beneficiaries were categorized into low-income or middle/high-income groups based on their insurance premiums. Using a two-part model, the odds ratios (ORs) and 95\% confidence intervals (Cls) for the utilization of home-based rehabilitation and home help services in the month following care needs certification were estimated using logistic regression analysis, and the risk ratios (RRs) of service expenditures were estimated using a generalized linear model for gamma-distributed data with a log-link function.

Results: Among 3770 subjects, 681 (18.1\%) used home-based rehabilitation and 1163 (30.8\%) used home help services. There were 1419 (37.6\%) low-income subjects, who were significantly less likely to use (OR: 0.813; 95\%Cl: 0.670-0.987) and spend on (RR: 0.910; 95\%Cl: 0.829-0.999) home-based rehabilitation services than middle/highincome subjects. Conversely, low-income subjects were significantly more likely to use (OR: $1.432 ; 95 \% \mathrm{Cl}: 1.232-$ 1.664) but less likely to spend on (RR: $0.888 ; 95 \% \mathrm{Cl}$ : $0.799-0.986$ ) home help services than middle/high-income subjects.

Conclusion: Household income was associated with the utilization of long-term home care services. To improve access to these services, the LTC insurance system should examine ways to decrease the financial burden of lowincome beneficiaries and encourage service utilization.
\end{abstract}

Keywords: Aging, Economic status, Long-term care services, Claims data, Two-part model

\footnotetext{
* Correspondence: rumikot-tky@umin.ac.jp

${ }^{1}$ Human Care Research Team, Tokyo Metropolitan Institute of Gerontology,

35-2 Sakae-cho, Itabashi-ku, Tokyo 173-0015, Japan

${ }^{2}$ Dia Foundation for Research on Ageing Societies, Tokyo, Japan

Full list of author information is available at the end of the article
}

C The Author(s). 2020 Open Access This article is licensed under a Creative Commons Attribution 4.0 International License, which permits use, sharing, adaptation, distribution and reproduction in any medium or format, as long as you give appropriate credit to the original author(s) and the source, provide a link to the Creative Commons licence, and indicate if changes were made. The images or other third party material in this article are included in the article's Creative Commons licence, unless indicated otherwise in a credit line to the material. If material is not included in the article's Creative Commons licence and your intended use is not permitted by statutory regulation or exceeds the permitted use, you will need to obtain permission directly from the copyright holder. To view a copy of this licence, visit http://creativecommons.org/licenses/by/4.0/ The Creative Commons Public Domain Dedication waiver (http://creativecommons.org/publicdomain/zero/1.0/) applies to the data made available in this article, unless otherwise stated in a credit line to the data. 


\section{Background}

As the global population continues to age, long-term care (LTC) insurance is becoming increasingly important as a social security system for older adults with disabilities [1]. In Japan-the world's fastest aging country$13.8 \%$ of the population was aged $\geq 75$ years in 2017 , and this proportion is projected to reach $17.8 \%$ in 2025 [2]. Furthermore, the proportion of older Japanese adults receiving LTC services has steadily risen with advancing age [3]. With this rapid increase in the number of LTC insurance beneficiaries, there is a growing pressure to ensure that services are distributed equitably and sustainably according to each individual's need.

Japan's LTC insurance system is based on a fee-forservice model, and ostensibly provides freedom of choice regarding services and providers for beneficiaries and their families. However, there are two economic-based limitations to these choices. First, LTC insurance beneficiaries are assigned a care manager, who prepares an LTC plan based on the needs and preferences of each beneficiary and his/her family. Care managers generally select LTC services that do not exceed the allocated limit of service expenditures stipulated for each level of required care and care setting. Second, LTC insurance beneficiaries are charged $10-20 \%$ of LTC service costs as out-of-pocket payments (lower-income beneficiaries pay $10 \%)$. Therefore, care managers must not only consider each beneficiary's needs, but also their financial constraints. Due to these limitations, the level of household income is likely to affect LTC service utilization. Although it has been previously reported that unadjusted expenditures for LTC services were higher for low-income beneficiaries than those with higher income [4], another study found that LTC service expenditures for low-income beneficiaries were lower than those with higher income after adjusting for health status-related factors [5]. This difference of expenditures between income level may be due to the regressivity of the out-ofpocket burden, in which out-of-pocket payments account for a higher proportion of household income in lower-income beneficiaries than higher-income beneficiaries [6]. As a consequence, low-income beneficiaries may shy away from using services that are expensive or involve relatively higher minimum payments.

The Japanese LTC insurance system provides both home care services and institutional services, with each service type fulfilling different roles. Home care services include three major service types: home-visit nursing services, home help services, and home-based services provided by rehabilitation professionals (referred to here as "home-based rehabilitation services") [7]. A previous study reported that LTC beneficiaries with higher income levels were more likely to use home-visit nursing services than those with lower income levels, which may be due to the relatively high costs of these services [8]. As home-based rehabilitation services are also relatively expensive, we hypothesized that low-income beneficiaries may forgo using these services because of insufficient financial resources (Table 1). However, studies have yet to examine the associations of income levels with home help service and home-based rehabilitation service utilization. Home-based rehabilitation services contribute to improved functional capacity $[9,10]$ and prevent the escalation of care needs [11]. Moreover, LTC insurers in Japan pay an additional fee to home care agencies when home-based rehabilitation and home help service providers work together to enable older adults to perform activities of daily living and lead relatively independent lives [12]. Therefore, this study focuses on both home help services and home-based rehabilitation services.

Furthermore, LTC insurance beneficiaries burdened with high out-of-pocket payments for medical care may forgo the use of LTC services. Accordingly, a beneficiary's medical expenditures can potentially affect his/ her access to LTC services, and it is important to consider these expenditures when examining the association of household income with LTC service utilization. Insurance claims data are frequently used for health utilization and expenditure analyses, but the integrated study of LTC insurance claims and medical claims is hindered by the differing data formats. As a result, few studies have examined the association between household income and LTC service utilization with adjustments for the effects of medical expenditures. In order to contribute to the improvement of access to LTC services in Japan regardless of income, this study aimed to examine if household income was associated with the utilization and expenditures of home-based rehabilitation and home help services.

\section{Methods \\ Study design and setting}

This study adopted a cross-sectional design, and was conducted using data from residents of Kashiwa city, Chiba prefecture, Japan. The population, spread over an area of $114.74 \mathrm{~km}^{2}$, consisted of 405,099 residents in 2012; of these, $21.3 \%$ were aged $\geq 65$ years [13].

\section{Data sources}

We used five data sets: two insurance claims data sets (LTC insurance claims and medical claims) and three administrative data sets (care needs certification for LTC insurance, LTC insurance premium levels, and resident registry data). LTC insurance claims data included the expenditures and amount of LTC services each subject used per month. Medical claims data included each subject's diagnoses based on International Statistical 
Table 1 Examples of long-term home service unit durations and fees

\begin{tabular}{lll}
\hline & Duration of one unit & Fees per unit (USD) $^{\mathrm{a}}$ \\
\hline Home-based rehabilitation services & & 37.20 \\
Home-visit rehabilitation from medical facilities or nursing homes & $20 \mathrm{~min}$ & 38.54 \\
Home-visit rehabilitation from visiting nurse agencies & $20 \mathrm{~min}$ & 118.29 \\
Day care services (for persons with care needs level 3) & $6-8 \mathrm{~h}$ & 30.98 \\
Home help services & & $20-30 \mathrm{~min}$ \\
Physical care & $20-45 \mathrm{~min}$ & 23.17 \\
Daily living support &
\end{tabular}

${ }^{a}$ Expenditures were converted to USD from JPY (US\$1 = ¥82, March 31, 2012)

LTC Long-term care.

Classification of Diseases and Related Health Problems 10th Revision (ICD-10) codes, drug prescriptions, and medical expenditures. Data on care needs certification for LTC insurance included each subject's certified level of required care and his/her degrees of physical and cognitive impairment [14]. In Japan, the levels of required care are categorized into two care support levels (1-2; indicative of the need for preventive care) and five care needs levels (1-5; indicative of the need for LTC), with higher levels signifying greater need. Each beneficiary's level of required care is determined by computer-based assessment and a panel of specialists appointed by the local government [7]. LTC insurance premium levels were used to indicate household income. Resident registry data included the following socio-demographic characteristics: birth year (provided in five-year brackets to reduce the risk of personal identification), sex, and dwelling type. Anonymous identification numbers were created randomly from insurance numbers for each of the five data sets, and were linked to specific individuals across data sets.

\section{Subjects}

The study subjects comprised long-term home care service users aged $\geq 65$ years who were certified as having care needs levels $1-5$ by the local government between April 2012 and August 2013. The subject selection process is presented in Fig. 1. From among LTC insurance beneficiaries aged $\geq 65$ years who received care needs certification between April 2012 and August $2013(n=9860)$, we excluded those with care support levels 1 or $2(n=1849)$, those who were admitted to LTC facilities $(n=1382)$, those who were admitted to hospitals $(n=101)$, and those who did not use any long-term home care services during the month after care needs certification $(n=2222)$. Subjects who did not use any long-term home care services during the month after care needs certification were considered to have no actual or specific need for these services at the time of certification, and were therefore excluded from analysis. After this initial exclusion, there were 4306 candidate subjects.
Next, subjects were excluded if they lacked data on LTC insurance premium levels $(n=213)$, were receiving public welfare (i.e., living below the poverty line as determined by the national government and receiving financial support for all medical and LTC service expenditures under public assistance programs; $n=207$ ) [15], lacked data on cognitive function $(n=47)$, or were aged < 75 years with no medical claims data for community-based health insurance $(n=69)$. The final number of study subjects for analysis was 3770 .

During the selection process, we were unable to completely exclude all persons aged $<65$ years because the birth year data were provided in five-year brackets. Additionally, we only had access to community-based health insurance data; therefore, we excluded people aged $<75$ years without community-based health insurance data. For people aged $<75$ years, public health insurance in Japan is divided into employee-based and communitybased insurance. Employee-based health insurance provides coverage to people (and their dependents) who work at private companies, whereas community-based health insurance provides coverage to people who are self-employed or retired. In contrast, all older persons aged $\geq 75$ years must enroll in the Late Elder's Health Insurance system [16] and this data was available. Accordingly, all subjects aged $\geq 75$ years were included in analysis.

\section{Measurements \\ Dependent variables}

The dependent variables were the utilization of homebased rehabilitation services and the utilization of home help services in the month following care needs certification. Home-based rehabilitation services comprise home-visit rehabilitation services from medical facilities or nursing homes, home-visit rehabilitation services from visiting nurse agencies, and day care services (Table 1). Home help services comprise physical care, daily living support, and support for getting on and off transit vehicles when visiting a hospital (Table 1); subjects who were provided only one of these services were 


\section{LTC insurance care needs certification data}

LTC insurance beneficiaries $(n=9,860)$

- Aged $\geq 65$ years

- Care needs certified between April 2012 and August 2013

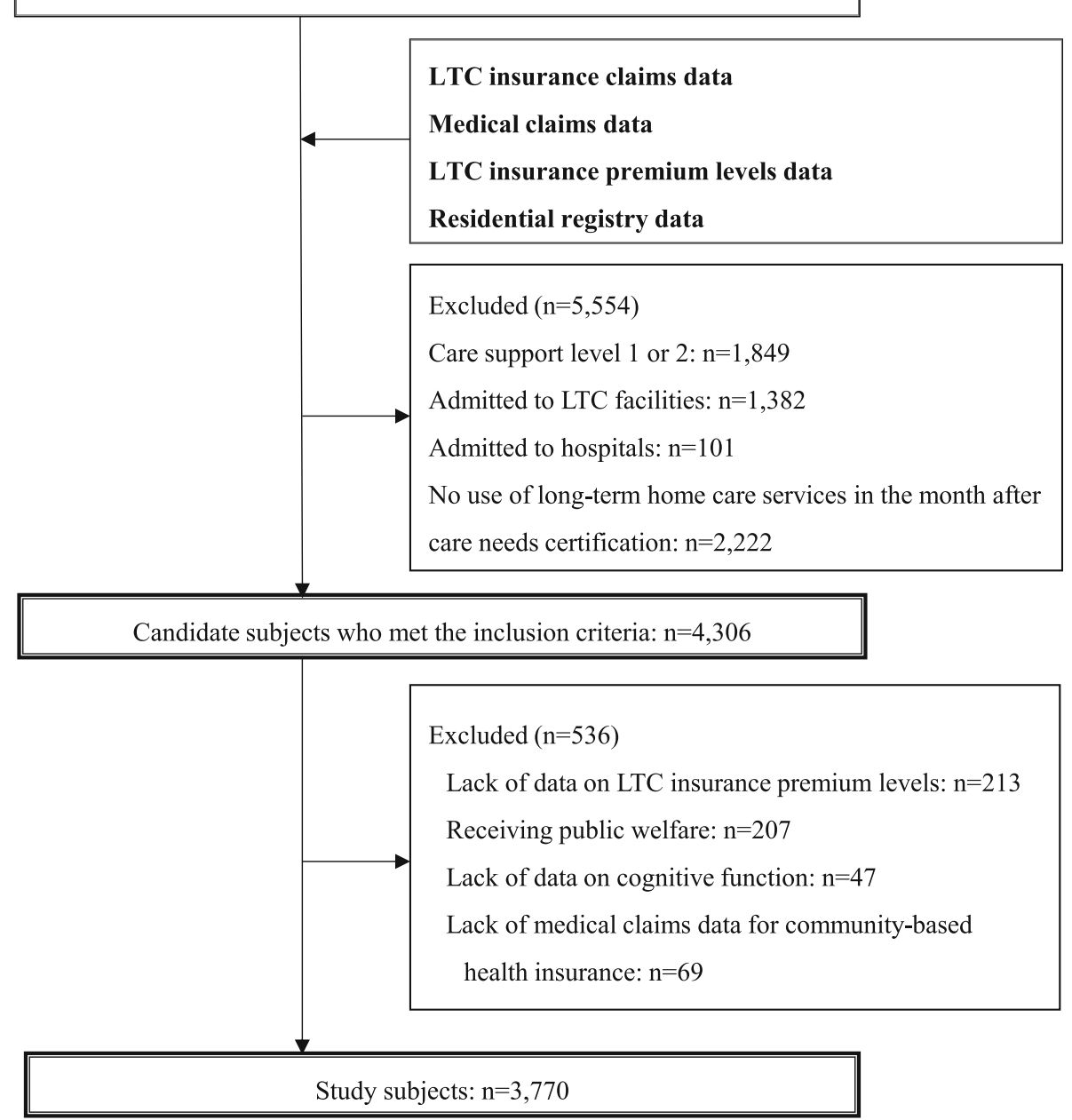

Fig. 1 Process of selecting analyzable subjects. LTC = long-term care

categorized as using "single-type" services, and subjects who were provided two or more of these services were categorized as using "multiple-type" services.

The utilization of each service was examined based on whether a subject used that service at least once (use or non-use) during the month after care needs certification, as well as the corresponding expenditure. The reason for focusing on service utilization 1 month after certification was that this approach provides insight into each subject's service needs at the time of care needs certification. Expenditures were calculated by multiplying the frequency of each service used per month by the unit cost (stipulated by the national government). The expenditures included both out-of-pocket payments and the amount paid by LTC insurance. These were converted from JPY to USD using the exchange rate on March 31, 2012 (US\$1 = ¥82) [17].

\section{Independent variable}

The independent variable of interest was household income, which was defined as the total income of each beneficiary and his/her household members. Household income was ascertained from each beneficiary's LTC insurance premium level, which ranged from level 1 (persons receiving public assistance) to level 16 (persons who are taxed individually with a total annual income $\geq 10$ million yen). Level 4 (persons who are not taxed individually, but have family members paying taxes within 
the same household) corresponds to the standard household income level where standard premium rates apply. We excluded subjects with level 1 household income as they did not have any available medical claims data. Based on these levels, subjects with levels 2 or 3 (persons and family members who are exempt from resident taxation) were categorized as "low income", and subjects with levels 4 to 16 were categorized as "middle/high income". This threshold is frequently used by the Japanese government for policymaking aimed at reducing the economic burden of financially disadvantaged individuals [18].

\section{Covariates}

The following socio-demographic variables were used as covariates: age group, sex, dwelling type (detached housing or multiple-unit housing), care needs level, physical function, cognitive function, and chronic diseases. Age was grouped into three categories to simulate the age categorization of older people proposed by the Japan Gerontological Society and the Japan Geriatrics Society [19]: 62-71 years (born in 1940 or later), 72-81 years (born between 1930 and 1939), and $\geq 82$ years (born in 1929 or earlier). Care needs levels ranged from the lowest (level 1) to the most severe (level 5) [7].

Physical and cognitive function in relation to activities of daily living (ADL) was assessed based on the nationally standardized methods designated by the Japanese Ministry of Health, Labour and Welfare; physical function was assessed using the "degree of independent daily living for older disabled people" and cognitive function was assessed using the "degree of independent daily living for older people with dementia" [14]. Physical function was categorized into "independent" (independent or Level J: patient is able to go out independently), "mild" (Level A: patient requires assistance when going out), "moderate" (Level B: patient requires assistance indoors and sometimes for sitting up), and "severe" (Level C: patient is bedridden). Similarly, cognitive function was categorized into "independent" (independent or Rank I: patient is able to live independently), "mild" (Rank II: patient can generally live independently under observation despite some daily-life-disturbing symptoms, behaviors, and communication problems), "moderate" (Rank III: patient requires assistance in daily life), and "severe" (Rank IV: patient requires frequent assistance and Rank M: patient has marked psychiatric symptoms requiring expert management).

Using ICD-10 codes, we included the following five chronic diseases that represent the main causes of LTC insurance certification: cerebrovascular disease (ICD-10 codes: I60-I63, I69), joint disorders (M15-M17, M19, M43, M47, M48, M50, M51), heart disease (I20-25, I48), dementia (F00-F02, G30, G31), and Parkinson's disease (G20) [20]. To increase the certainty of the recorded diagnoses, we identified four of these diseases (excluding cerebrovascular disease) using a previously described method based on a combination of ICD-10 codes and the recorded administration of drug classes commonly prescribed to treat these diseases in Japan [21]. We identified individuals with any of the four chronic diseases if their outpatient claims data showed the prescription of a relevant drug class in the same or following month in which the target disease was diagnosed.

The use of home-visit nursing services was also included to adjust for the utilization of each service because home help service users are reportedly more likely to also use home-visit nursing [8]. In addition, beneficiaries may choose to forgo the use of a specific service due to financial constraints, and the utilization of one service may therefore affect the utilization of another. We adjusted for the utilization of home help services when examining the utilization of home-based rehabilitation services, and vice versa.

In patients with financial constraints, the use of medical care may also influence the decision to use LTC services. To account for this potential influence, medical expenditure was included in the analysis. Medical expenditure was defined as the mean medical expenditure for the month of care needs certification and the subsequent month, and was categorized into tertiles: lower group ( $\leq$ US\$142.62), middle group (US\$142.63-551.59), and higher group ( $\geq$ US\$551.60).

\section{Statistical analysis}

To examine the association of the socio-demographic characteristics with household income, we determined the number and percentage of subjects for each characteristic; these characteristics were compared between low-income beneficiaries and middle/high-income beneficiaries using the $x^{2}$ test. Next, to examine the association of the socio-demographic characteristics with home-based rehabilitation and home help service utilization, we determined the number and percentage of subjects for each characteristic, mean and standard deviation of expenditures, median expenditures, and the interquartile range of expenditures; these characteristics were compared between the use and non-use of each service using the $x^{2}$ test.

We then used a two-part model [22] to estimate the utilization probability and total expenditure of each service. Due to the expectation that there would be many zero values in the expenditures of each service, we selected the two-part model approach because of its usefulness in analyzing zero-inflated outcomes [23]. This allowed the identification and exclusion of subjects who did not use the target service and had no associated expenditures. The first part of the model involved a 
multivariate logistic regression analysis for all subjects. The effect size was defined for each LTC service as the odds ratio (OR) and 95\% confidence interval (95\% CI), which indicated the likelihood that low-income subjects would use a service relative to middle/high-income subjects. The second part of the model involved a generalized linear model for gamma-distributed data with a loglink function. The effect size was defined as the risk ratio (RR) and 95\% CI, which indicated the likelihood that low-income subjects would spend money on a service relative to middle/high-income subjects. Dementia was excluded as a chronic disease from the two-part model due to the multicollinearity between dementia and cognitive function.

All analyses were conducted using SPSS version 23.0 (SPSS Inc., Chicago, IL), and the significance threshold was set at $P=0.05$ (two-tailed).

\section{Results}

Table 2 shows the number and proportion of subjects using each service. Of the 3770 study subjects, $18.1 \%$ used home-based rehabilitation services and 30.8\% used home help services. Among those who used rehabilitation services, 19.2\% used home-visit rehabilitation from medical facilities or nursing homes, $11.7 \%$ used homevisit rehabilitation from visiting nurse agencies, and 69.0\% used day care services. Among those who used home help services, $5.5 \%$ used single-type services and 94.5\% used multiple-type services.

Table 3 shows the association of socio-demographic characteristics with household income. Approximately $37.6 \%$ of subjects were categorized into the low-income group. These subjects were significantly associated with older age, being female, living in multiple-unit housing, care needs levels 1 or 5 , and having severe cognitive impairment. Conversely, subjects in the low-income group were less likely to have cerebrovascular disease or heart disease.
As shown in Table 4 and Table 5, the proportion of subjects who used home-based rehabilitation services was significantly higher $(p<0.001)$ in the middle/highincome group $(20.2 \%)$ than in the low-income group (14.4\%). However, the proportion of subjects who used home help services was significantly higher $(p<0.001)$ in the low-income group (35.9\%) than in the middle/highincome group (27.8\%). The mean \pm standard deviation (SD) expenditure for home-based rehabilitation services was $786.2 \pm 530.5$ USD and the median expenditure was 661 USD. The mean \pm SD expenditure for home help services was $1113.9 \pm 1145.6$ USD and the median expenditure was 623 USD. Both service expenditures had right-skewed distributions.

Table 6 shows the association of household income with home-based rehabilitation service utilization and expenditures based on the two-part model. The first part showed that low-income subjects were significantly less likely to use home-based rehabilitation services than middle/high-income subjects (OR: 0.813; 95\% CI: 0.6700.987). In the second part of the model, expenditures for home-based rehabilitation services were found to be significantly lower for low-income subjects than for middle/high-income subjects (RR: 0.910; 95\% CI: 0.8290.999). Moreover, subjects in the middle (OR: $0.782,95 \%$ CI: $0.632-0.968$ ) and higher (OR: $0.590,95 \%$ CI: 0.470 0.741 ) medical expenditure groups were significantly less likely to use home-based rehabilitation services than those in the lower medical expenditure group. However, medical expenditures were not significantly associated with home-based rehabilitation expenditures.

Table 7 shows the association of household income with home help service utilization and expenditures based on the two-part model. The first part showed that low-income subjects were significantly more likely to use home help services than middle/high-income subjects (OR: 1.432; 95\% CI: 1.232-1.664). However, the second part showed that expenditures for home help services

Table 2 Numbers and proportions of subjects using home-based rehabilitation and home help services $(n=3770)$

\begin{tabular}{ll}
\hline & $\mathrm{n}(\%)$ \\
\hline Home-based rehabilitation services: Use & $681(18.1)$ \\
Type of service & $131(19.2)$ \\
$\quad$ Home-visit rehabilitation from medical facilities or nursing homes & 80 (11.7) \\
$\quad$ Home-visit rehabilitation from visiting nurse agencies & 470 (69.0) \\
$\quad$ Day care services & 1163 (30.8) \\
Home help services: Use & 64 (5.5) \\
Type of service & 1099 (94.5) \\
$\quad$ Single & \\
Multiple &
\end{tabular}

${ }^{a}$ Home help services comprise physical care, daily living support, and support for getting on and off transit vehicles; subjects who were provided only one of these services were categorized as using "single-type" services, and subjects who were provided two or more of these services were categorized as using "multiple-type" services 
Table 3 Socio-demographic characteristics by household income $(n=3770)$

\begin{tabular}{|c|c|c|c|c|}
\hline & \multirow{2}{*}{$\begin{array}{l}\text { Total } \\
\text { n (\%) }\end{array}$} & \multicolumn{2}{|c|}{ Household income } & \multirow[t]{2}{*}{$P$ value } \\
\hline & & $\begin{array}{l}\text { Low income } \\
\mathrm{n}(\%)\end{array}$ & $\begin{array}{l}\text { Middle/high income } \\
\mathrm{n}(\%)\end{array}$ & \\
\hline Total & $3770(100.0)$ & 1419 (37.6) & $2351(62.4)$ & \\
\hline \multicolumn{5}{|l|}{ Age (years) } \\
\hline $62-71$ & $395(10.5)$ & $125(8.8)$ & $270(11.5)$ & \multirow[t]{3}{*}{0.003} \\
\hline $72-81$ & $1318(35.0)$ & $474(33.4)$ & $844(35.9)$ & \\
\hline$\geq 82$ & $2057(54.6)$ & $820(57.8)$ & $1237(52.6)$ & \\
\hline \multicolumn{5}{|l|}{ Sex } \\
\hline Male & $1323(35.1)$ & $273(19.2)$ & $1050(44.7)$ & \multirow[t]{2}{*}{$<0.001$} \\
\hline Female & $2447(64.9)$ & $1146(80.8)$ & $1301(55.3)$ & \\
\hline \multicolumn{5}{|l|}{ Dwelling } \\
\hline Detached house & $2952(78.3)$ & $1056(74.4)$ & $1896(80.6)$ & \multirow[t]{2}{*}{$<0.001$} \\
\hline Multiple-unit housing & $818(21.7)$ & $363(25.6)$ & $455(19.4)$ & \\
\hline \multicolumn{5}{|l|}{ Care needs level } \\
\hline Care needs level 1 & $944(25.0)$ & $389(27.4)$ & $555(23.6)$ & \multirow[t]{5}{*}{0.027} \\
\hline Care needs level 2 & $1108(29.4)$ & $393(27.7)$ & $715(30.4)$ & \\
\hline Care needs level 3 & $712(18.9)$ & $257(18.1)$ & $455(19.4)$ & \\
\hline Care needs level 4 & $548(14.5)$ & $194(13.7)$ & $354(15.1)$ & \\
\hline Care needs level 5 & $458(12.1)$ & $186(13.1)$ & $272(11.6)$ & \\
\hline \multicolumn{5}{|l|}{ Physical function } \\
\hline Independent (Independent and Level J) & $382(10.1)$ & $152(10.7)$ & $230(9.8)$ & \multirow[t]{4}{*}{0.708} \\
\hline Mild (Level A) & $1925(51.1)$ & $718(50.6)$ & $1207(51.3)$ & \\
\hline Moderate (Level B) & $1012(26.8)$ & $386(27.2)$ & $626(26.6)$ & \\
\hline Severe (Level C) & $451(12.0)$ & $163(11.5)$ & $288(12.3)$ & \\
\hline \multicolumn{5}{|l|}{ Cognitive function } \\
\hline Independent (Independent and Rank I) & $1435(38.1)$ & $498(35.1)$ & $937(39.9)$ & \multirow[t]{4}{*}{0.034} \\
\hline Mild (Rank II) & $1098(29.1)$ & $429(30.2)$ & $669(28.5)$ & \\
\hline Moderate (Rank III) & $814(21.6)$ & $322(22.7)$ & $492(20.9)$ & \\
\hline Severe (Rank IV and Rank M) & $423(11.2)$ & $170(12.0)$ & $253(10.8)$ & \\
\hline \multicolumn{5}{|l|}{ Chronic diseases } \\
\hline Dementia & $1064(28.2)$ & $402(28.3)$ & $662(28.2)$ & 0.910 \\
\hline Cerebrovascular disease & $1529(40.6)$ & $535(37.7)$ & $994(42.3)$ & 0.006 \\
\hline Joint disorders & $1523(40.4)$ & $597(42.1)$ & $926(39.4)$ & 0.104 \\
\hline Heart disease & $1241(32.9)$ & $429(30.2)$ & $812(34.5)$ & 0.006 \\
\hline Parkinson's disease & $247(6.6)$ & $80(5.6)$ & $167(7.1)$ & 0.078 \\
\hline Home-visit nursing: Use & $372(9.9)$ & $117(8.2)$ & $255(10.8)$ & 0.009 \\
\hline \multicolumn{5}{|l|}{ Medical Expenditures (USD) ${ }^{b}$} \\
\hline Lower group ( $\leq \$ 142.62)$ & $1257(33.3)$ & $502(35.4)$ & $755(32.1)$ & \multirow[t]{3}{*}{0.060} \\
\hline Middle group (\$142.63-551.59) & $1257(33.3)$ & $473(33.3)$ & $784(33.3)$ & \\
\hline Higher group ( $\geq \$ 551.60)$ & $1256(33.3)$ & $444(31.3)$ & $812(34.5)$ & \\
\hline
\end{tabular}

\footnotetext{
${ }^{a} x^{2}$ test

b Expenditures were converted to USD from JPY (US\$1 = ¥82, March 31, 2012). Expenditures were calculated as the mean medical expenditure for the month of care needs certification and the subsequent month, and was categorized into tertiles: lower group ( $\leq$ US\$142.62), middle group (US\$142.63-551.59), and higher group ( $\geq$ US\$551.60)
} 
Table 4 Association of socio-demographic characteristics with the utilization of home-based rehabilitation services $(n=3770)$

\begin{tabular}{|c|c|c|c|c|c|c|}
\hline & \multicolumn{5}{|c|}{ Home-based rehabilitation services } & \multirow[b]{3}{*}{$P$ value $e^{\mathrm{d}, e}$} \\
\hline & \multirow{2}{*}{$\begin{array}{l}\text { Non-use } \\
n(\%)\end{array}$} & \multirow{2}{*}{$\begin{array}{l}\text { Use } \\
\text { n (\%) }\end{array}$} & \multirow[b]{2}{*}{$P$ value ${ }^{a}$} & \multicolumn{2}{|c|}{ Expenditures $^{\mathrm{b}, \mathrm{c}}$} & \\
\hline & & & & Mean $\pm S D$ & Median (IQR) & \\
\hline Total & $3089(81.9)$ & $681(18.1)$ & & $786.2 \pm 530.5$ & $661(321-1143)$ & \\
\hline \multicolumn{7}{|l|}{ Household income } \\
\hline Middle/high income & $1875(79.8)$ & $476(20.2)$ & $<0.001$ & $804.1 \pm 533.1$ & $681(324-1169)$ & 0.156 \\
\hline Low income & $1214(85.6)$ & $205(14.4)$ & & $744.4 \pm 523.4$ & $642(313-1056)$ & \\
\hline \multicolumn{7}{|l|}{ Age (years) } \\
\hline $62-71$ & $262(66.3)$ & $133(33.7)$ & $<0.001$ & $835.9 \pm 550.3$ & $753(326-1247)$ & 0.496 \\
\hline $72-81$ & $1057(80.2)$ & $261(19.8)$ & & $764.6 \pm 527.4$ & $626(321-1082)$ & \\
\hline$\geq 82$ & $1770(86.0)$ & $287(14.0)$ & & $782.6 \pm 524.3$ & $681(321-1152)$ & \\
\hline \multicolumn{7}{|l|}{ Sex } \\
\hline Male & $1010(76.3)$ & $313(23.7)$ & $<0.001$ & $804.9 \pm 532.3$ & $731(313-1180)$ & 0.441 \\
\hline Female & $2079(85.0)$ & $368(15.0)$ & & $770.2 \pm 529.2$ & $641(322-1111)$ & \\
\hline \multicolumn{7}{|l|}{ Dwelling } \\
\hline Detached house & $2376(80.5)$ & $576(19.5)$ & $<0.001$ & $801.6 \pm 545.0$ & $669(321-1169)$ & 0.207 \\
\hline Multiple-unit housing & $713(87.2)$ & $105(12.8)$ & & $701.0 \pm 435.0$ & $596(321-999)$ & \\
\hline \multicolumn{7}{|l|}{ Care needs level } \\
\hline Care needs level 1 & $780(82.6)$ & $164(17.4)$ & 0.228 & $648.6 \pm 347.0$ & $601(331-872)$ & $<0.001$ \\
\hline Care needs level 2 & $893(80.6)$ & $215(19.4)$ & & $817.2 \pm 389.8$ & $754(385-1115)$ & \\
\hline Care needs level 3 & $578(81.2)$ & $134(18.8)$ & & $967.7 \pm 593.7$ & $968(449-1311)$ & \\
\hline Care needs level 4 & $466(85.0)$ & $82(15.0)$ & & $827.8 \pm 650.5$ & $491(313-1368)$ & \\
\hline Care needs level 5 & $372(81.2)$ & $86(18.8)$ & & $647.9 \pm 591.7$ & $324(235-883)$ & \\
\hline \multicolumn{7}{|l|}{ Physical function } \\
\hline Independent (Independent and Level J) & $327(85.6)$ & $55(14.4)$ & 0.127 & $695.2 \pm 389.2$ & $648(420-875)$ & $<0.001$ \\
\hline Mild (Level A) & $1584(82.3)$ & $341(17.7)$ & & $826.9 \pm 497.5$ & $757(395-1169)$ & \\
\hline Moderate (Level B) & $817(80.7)$ & $195(19.3)$ & & $811.7 \pm 589.6$ & $665(313-1185)$ & \\
\hline Severe (Level C) & $361(80.0)$ & $90(20.0)$ & & $631.8 \pm 564.1$ & $350(235-883)$ & \\
\hline \multicolumn{7}{|l|}{ Cognitive function } \\
\hline Independent (Independent and Rank I) & $1074(74.8)$ & $361(25.2)$ & $<0.001$ & $764.2 \pm 493.2$ & $642(321-1120)$ & 0.003 \\
\hline Mild (Rank II) & $935(85.2)$ & $163(14.8)$ & & $852.2 \pm 550.9$ & $798(391-1256)$ & \\
\hline Moderate (Rank III) & $705(86.6)$ & 109 (13.4) & & $854.3 \pm 607.2$ & $741(330-1226)$ & \\
\hline Severe (Rank IV and Rank M) & $375(88.7)$ & $48(11.3)$ & & $571.4 \pm 488.6$ & $330(247-648)$ & \\
\hline \multicolumn{7}{|l|}{ Chronic diseases } \\
\hline \multicolumn{7}{|l|}{ Dementia } \\
\hline Present & $951(89.4)$ & $113(10.6)$ & $<0.001$ & $779.1 \pm 515.7$ & $691(390-1009)$ & 0.852 \\
\hline Absent & $2138(79.0)$ & $568(21.0)$ & & $787.5 \pm 533.8$ & $647(320-1167)$ & \\
\hline \multicolumn{7}{|l|}{ Cerebrovascular disease } \\
\hline Present & $1182(77.3)$ & $347(22.7)$ & $<0.001$ & $852.5 \pm 532.1$ & $754(374-1244)$ & $<0.001$ \\
\hline Absent & $1907(85.1)$ & $334(14.9)$ & & $717.2 \pm 520.7$ & $557(313-1016)$ & \\
\hline \multicolumn{7}{|l|}{ Joint disorders } \\
\hline Present & 1213 (79.6) & $310(20.4)$ & 0.003 & $736.4 \pm 492.5$ & $635(313-1102)$ & 0.047 \\
\hline Absent & $1876(83.5)$ & $371(16.5)$ & & $827.7 \pm 557.5$ & 705 (332-1181) & \\
\hline \multicolumn{7}{|l|}{ Heart disease } \\
\hline Present & $1014(81.7)$ & $227(18.3)$ & 0.799 & $740.6 \pm 527.3$ & $626(313-1044)$ & 0.075 \\
\hline
\end{tabular}


Table 4 Association of socio-demographic characteristics with the utilization of home-based rehabilitation services $(n=3770)$ (Continued)

\begin{tabular}{|c|c|c|c|c|c|c|}
\hline & \multicolumn{5}{|c|}{ Home-based rehabilitation services } & \multirow[b]{3}{*}{$P$ value ${ }^{\mathrm{d}, \mathrm{e}}$} \\
\hline & \multirow{2}{*}{$\begin{array}{l}\text { Non-use } \\
\text { n (\%) }\end{array}$} & \multirow{2}{*}{$\begin{array}{l}\text { Use } \\
\text { n (\%) }\end{array}$} & \multirow[b]{2}{*}{$P$ value $^{a}$} & \multicolumn{2}{|c|}{ Expenditures ${ }^{b, c}$} & \\
\hline & & & & Mean \pm SD & Median (IQR) & \\
\hline Absent & $2075(82.0)$ & $454(18.0)$ & & $808.9 \pm 531.2$ & 709 (324-1169) & \\
\hline \multicolumn{7}{|l|}{ Parkinson's disease } \\
\hline Present & $176(71.3)$ & $71(28.7)$ & $<0.001$ & $784.4 \pm 513.0$ & $697(313-1169)$ & 0.980 \\
\hline Absent & $2913(82.7)$ & $610(17.3)$ & & $786.3 \pm 532.9$ & $659(321-1139)$ & \\
\hline \multicolumn{7}{|l|}{ Home-based rehabilitation services } \\
\hline Use & - & - & - & - & - & \\
\hline Non-use & - & - & & - & - & \\
\hline \multicolumn{7}{|l|}{ Home help services } \\
\hline Use & $966(83.1)$ & $197(16.9)$ & 0.231 & $637.7 \pm 482.5$ & $433(311-959)$ & $<0.001$ \\
\hline Non-use & $2123(81.4)$ & $484(18.6)$ & & $846.5 \pm 537.7$ & $756(364-1218)$ & \\
\hline \multicolumn{7}{|l|}{ Home-visit nursing } \\
\hline Use & $269(72.3)$ & $103(27.7)$ & $<0.001$ & $504.9 \pm 425.8$ & $321(235-642)$ & $<0.001$ \\
\hline Non-use & $2820(83.0)$ & $578(17.0)$ & & $836.2 \pm 532.0$ & $753(370-1176)$ & \\
\hline \multicolumn{7}{|l|}{ Medical expenditures (USD) ${ }^{b}$} \\
\hline Lower group $(\leq \$ 142.62)$ & $1015(80.7)$ & $242(19.3)$ & 0.178 & $895.1 \pm 549.9$ & $847(432-1264)$ & $<0.001$ \\
\hline Middle group (\$142.63-551.59) & $1025(81.5)$ & $232(18.5)$ & & $774.3 \pm 479.0$ & $698(325-1073)$ & \\
\hline Higher group $(\geq \$ 551.60)$ & $1049(83.5)$ & $207(16.5)$ & & $672.0 \pm 539.2$ & 439 (276-973) & \\
\hline
\end{tabular}

${ }^{a} x^{2}$ test

b Expenditures were converted to USD from JPY (US\$1 $=¥ 82$, March 1, 2012). Expenditures were calculated as the mean medical expenditure for the month of care needs certification and the subsequent month, and were categorized into tertiles: lower group ( $\leq$ US\$142.62), middle group (US\$142.63-551.59), and higher group $(\geq U S \$ 551.60)$

c Expenditures were calculated using only subjects who used each service

d Mann-Whitney $U$ test

${ }^{e}$ Kruskal-Wallis test

IQR Interquartile range; SD Standard deviation

were significantly lower for low-income subjects than for middle/high-income subjects (RR: 0.888; 95\% CI: 0.7990.986). When compared with subjects in the lower medical expenditure group, subjects in the higher medical expenditure group were significantly more likely to use home help services (OR: 1.206, 95\% CI: 1.004-1.448) and incur higher expenditures (RR: 1.274, 95\% CI: 1.124-1.444).

\section{Discussion}

This is, to the best of our knowledge, the first study to demonstrate the association of household income with the utilization of home-based rehabilitation and home help services. The study was undertaken to make up for the lack of research on the differences between these two service types. When compared with middle/high-income subjects, low-income subjects were significantly less likely to use or spend money on home-based rehabilitation services. On the other hand, low-income subjects were significantly more likely to use home help services, but less likely to spend money on these services than middle/high-income subjects.

\section{Household income and home-based rehabilitation services}

Low-income subjects were found to have significantly lower utilization and expenditures of home-based rehabilitation services than middle/high-income subjects. This may be because low-income beneficiaries avoid home-based rehabilitation services when choosing LTC services within their allocated expenditure limit. There are two possible reasons for this: first, low-income beneficiaries may have a more present-oriented time preference, i.e., they are more likely to choose immediate utility over delayed utility $[24,25]$. Home-based rehabilitation services usually require several weeks or months before meeting the beneficiaries' minimum expectations, such as improvements in functional capacity. In contrast, home help services can immediately meet the beneficiaries' needs by supporting their ADL, such as bathing and housework. Thus, even if beneficiaries require both services, those with low household income may not choose home-based rehabilitation services due to their time preference. Another possible reason is the difference in service fees. Our findings were consistent with those of a 
Table 5 Association of socio-demographic characteristics with the utilization of home help services $(n=3770)$

\begin{tabular}{|c|c|c|c|c|c|c|}
\hline & \multicolumn{5}{|c|}{ Home help services } & \multirow[b]{3}{*}{$P$ value $e^{\mathrm{d}, e}$} \\
\hline & \multirow{2}{*}{$\begin{array}{l}\text { Non-use } \\
n(\%)\end{array}$} & \multirow{2}{*}{$\begin{array}{l}\text { Use } \\
\text { n (\%) }\end{array}$} & \multirow[b]{2}{*}{$P$ value ${ }^{a}$} & \multicolumn{2}{|l|}{ Expenditures $^{b, c}$} & \\
\hline & & & & Mean \pm SD & Median (IQR) & \\
\hline Total & $2607(69.2)$ & $1163(30.8)$ & & $1113.9 \pm 1145.6$ & $623(269-1605)$ & \\
\hline \multicolumn{7}{|l|}{ Household income } \\
\hline Middle/high income & $1697(72.2)$ & $654(27.8)$ & $<0.001$ & $1134.8 \pm 1130.6$ & $668(281-1669)$ & 0.163 \\
\hline Low income & $910(64.1)$ & $509(35.9)$ & & $1087.1 \pm 1165.1$ & $583(253-1559)$ & \\
\hline \multicolumn{7}{|l|}{ Age (years) } \\
\hline $62-71$ & $285(72.2)$ & $110(27.8)$ & 0.173 & $885.3 \pm 989.8$ & $544(227-1200)$ & $<0.001$ \\
\hline $72-81$ & $890(67.5)$ & $428(32.5)$ & & $956.5 \pm 1038.4$ & $527(245-1292)$ & \\
\hline$\geq 82$ & $1432(69.6)$ & $625(30.4)$ & & $1261.9 \pm 1219.3$ & 753 (308-2011) & \\
\hline \multicolumn{7}{|l|}{ Sex } \\
\hline Male & $949(71.7)$ & $374(28.3)$ & 0.012 & $1024.8 \pm 1117.7$ & 547 (233-1459) & 0.011 \\
\hline Female & $1658(67.8)$ & $789(32.2)$ & & $1156.1 \pm 1156.9$ & $663(295-1703)$ & \\
\hline \multicolumn{7}{|l|}{ Dwelling } \\
\hline Detached house & $2096(71.0)$ & $856(29.0)$ & $<0.001$ & $1076.9 \pm 1122.9$ & $593(265-1500)$ & 0.144 \\
\hline Multiple-unit housing & $511(62.5)$ & $307(37.5)$ & & $1217.2 \pm 1202.3$ & 704 (294-1870) & \\
\hline \multicolumn{7}{|l|}{ Care needs level } \\
\hline Care needs level 1 & $647(68.5)$ & $297(31.5)$ & $<0.001$ & $504.1 \pm 453.4$ & $359(205-612)$ & $<0.001$ \\
\hline Care needs level 2 & $800(72.2)$ & $308(27.8)$ & & $670.0 \pm 605.2$ & 477 (212-931) & \\
\hline Care needs level 3 & $522(73.3)$ & $190(26.7)$ & & $1230.3 \pm 1039.7$ & 912 (336-2002) & \\
\hline Care needs level 4 & $358(65.3)$ & $190(34.7)$ & & $1732.7 \pm 1383.7$ & $1396(462-3100)$ & \\
\hline Care needs level 5 & $280(61.1)$ & $178(38.9)$ & & $2114.8 \pm 1427.6$ & $1678(856-3509)$ & \\
\hline \multicolumn{7}{|l|}{ Physical function } \\
\hline Independent (Independent and Level J) & $236(61.8)$ & $146(38.2)$ & $<0.001$ & $439.4 \pm 403.6$ & $302(155-566)$ & $<0.001$ \\
\hline Mild (Level A) & $1418(73.7)$ & $507(26.3)$ & & $823.2 \pm 840.2$ & $482(235-1105)$ & \\
\hline Moderate (Level B) & $680(67.2)$ & $332(32.8)$ & & $1388.8 \pm 1289.4$ & $855(340-2199)$ & \\
\hline Severe (Level C) & $273(60.5)$ & $178(39.5)$ & & $1982.6 \pm 1355.5$ & $1637(857-3124)$ & \\
\hline \multicolumn{7}{|l|}{ Cognitive function } \\
\hline Independent (Independent and Rank I) & $961(67.0)$ & $474(33.0)$ & 0.071 & $749.4 \pm 832.0$ & 459 (226-936) & $<0.001$ \\
\hline Mild (Rank II) & $760(69.2)$ & $338(30.8)$ & & $1098.8 \pm 1093.2$ & $681(293-1654)$ & \\
\hline Moderate (Rank III) & $587(72.1)$ & $227(27.9)$ & & $1552.7 \pm 1327.1$ & $1168(410-2372)$ & \\
\hline Severe (Rank IV and Rank M) & $299(70.7)$ & $124(29.3)$ & & $1745.5 \pm 1398.4$ & 1419 (510-2990) & \\
\hline \multicolumn{7}{|l|}{ Chronic diseases } \\
\hline \multicolumn{7}{|l|}{ Dementia } \\
\hline Present & $780(73.3)$ & $284(26.7)$ & 0.001 & $1400.0 \pm 1288.3$ & $877(336-2171)$ & $<0.001$ \\
\hline Absent & $1827(67.5)$ & $879(32.5)$ & & $1021.5 \pm 1080.2$ & $584(256-2990)$ & \\
\hline \multicolumn{7}{|l|}{ Cerebrovascular disease } \\
\hline Present & $1075(70.3)$ & $454(29.7)$ & 0.204 & $1111.7 \pm 1152.3$ & $614(273-1592)$ & 0.999 \\
\hline Absent & $1532(68.4)$ & 709 (31.6) & & $1115.3 \pm 1142.1$ & $633(267-1651)$ & \\
\hline \multicolumn{7}{|l|}{ Joint disorders } \\
\hline Present & $1015(66.6)$ & $508(33.4)$ & 0.006 & $1062.1 \pm 1137.2$ & $584(245-1506)$ & 0.040 \\
\hline Absent & $1592(70.9)$ & $655(29.1)$ & & $1154.1 \pm 1151.3$ & 671 (308-1678) & \\
\hline \multicolumn{7}{|l|}{ Heart disease } \\
\hline Present & $848(68.3)$ & $393(31.7)$ & 0.446 & $1087.0 \pm 1063.9$ & $663(279-1551)$ & 0.661 \\
\hline
\end{tabular}


Table 5 Association of socio-demographic characteristics with the utilization of home help services $(n=3770)$ (Continued)

\begin{tabular}{|c|c|c|c|c|c|c|}
\hline & \multicolumn{5}{|c|}{ Home help services } & \multirow[b]{3}{*}{$P$ value } \\
\hline & \multirow{2}{*}{$\begin{array}{l}\text { Non-use } \\
n(\%)\end{array}$} & \multirow{2}{*}{$\begin{array}{l}\text { Use } \\
\text { n (\%) }\end{array}$} & \multirow[b]{2}{*}{$P$ value $^{a}$} & \multicolumn{2}{|l|}{ Expenditures $^{\mathrm{b}, \mathrm{c}}$} & \\
\hline & & & & Mean \pm SD & Median (IQR) & \\
\hline Absent & $1759(69.6)$ & $770(30.4)$ & & $1127.7 \pm 1185.5$ & $604(265-1673)$ & \\
\hline \multicolumn{7}{|l|}{ Parkinson's disease } \\
\hline Present & $163(66.0)$ & $84(34.0)$ & 0.266 & $1576.4 \pm 1295.5$ & $1218(517-2510)$ & $<0.001$ \\
\hline Absent & $2444(69.4)$ & 1079 (30.6) & & $1077.9 \pm 1125.8$ & $593(265-1541)$ & \\
\hline \multicolumn{7}{|l|}{ Home-based rehabilitation services } \\
\hline Use & $484(71.1)$ & $197(28.9)$ & 0.231 & $905.6 \pm 905.4$ & $577(258-1242)$ & 0.079 \\
\hline Non-use & $2123(68.7)$ & $966(31.3)$ & & $1156.4 \pm 1184.5$ & $642(271-1702)$ & \\
\hline \multicolumn{7}{|l|}{ Home help services } \\
\hline Use & - & - & - & - & - & \\
\hline Non-use & - & - & & - & - & \\
\hline \multicolumn{7}{|l|}{ Home-visit nursing } \\
\hline Use & $198(53.2)$ & $174(46.8)$ & $<0.001$ & $1194.2 \pm 1153.2$ & 763 (329-1709) & 0.105 \\
\hline Non-use & $2409(70.9)$ & $989(29.1)$ & & $1099.8 \pm 1144.2$ & $590(262-1589)$ & \\
\hline \multicolumn{7}{|l|}{ Medical expenditures (USD) ${ }^{b}$} \\
\hline Lower group $(\leq \$ 142.62)$ & $906(72.1)$ & $351(27.9)$ & 0.001 & $840.8 \pm 856.7$ & $525(246-1060)$ & $<0.001$ \\
\hline Middle group (\$142.63-551.59) & $882(70.2)$ & $375(29.8)$ & & $995.2 \pm 1066.8$ & $534(265-1354)$ & \\
\hline Higher group ( $\geq \$ 551.60$ ) & $819(65.2)$ & $437(34.8)$ & & $1435.2 \pm 1325.4$ & $893(310-2352)$ & \\
\hline \multicolumn{7}{|c|}{$\begin{array}{l}\text { a } X^{2} \text { test } \\
{ }^{b} \text { Expenditures were converted to USD from JP } \\
\text { care needs certification and the subsequent } \mathrm{m} \\
\text { group }(\geq U S \$ 551.60) \\
\text { c Expenditures were calculated using only subj } \\
\text { d Mann-Whitney } U \text { test } \\
{ }^{\mathrm{e}} \text { Kruskal-Wallis test } \\
\text { IQR Interquartile range; } S D \text { Standard deviation }\end{array}$} \\
\hline
\end{tabular}

previous study where LTC insurance beneficiaries in lower-income households used fewer home-visit nursing services than those in higher-income households [8]. Kashiwagi et al. [8] proposed that this was because homevisit nursing is substantially more expensive than home help services. Home-based rehabilitation services are also more expensive than home help services (Table 1), and the higher out-of-pocket payments may discourage lowincome beneficiaries from using the former. Moreover, beneficiaries who are near their allocated expenditure limit would be compelled to choose from among these services. In our study's population, the proportions of beneficiaries that used $>80 \%$ of the upper limit of LTC service expenditures were $28.3 \%$ in the low-income subjects and $23.4 \%$ in the middle/high-income subjects. Accordingly, low-income subjects may eschew home-based rehabilitation services to reduce their out-of-pocket payments.

Our analysis also showed that low-income subjects were less likely to spend money on home-based rehabilitation services. This was consistent with a previous study [5] that reported that lower household income was associated with reduced service utilization. Moreover, the increase in expenditures that accompanied worsening ADL was lower in low-income beneficiaries than higherincome beneficiaries. Sugisawa et al. [5] noted that LTC insurance beneficiaries with lower household income reduced their service-related expenditures to curtail their out-of-pocket spending. The low-income subjects in our study may also have chosen to reduce their use of home-based rehabilitation services to decrease their outof-pocket burden.

\section{Household income and home help services}

Low-income subjects were significantly more likely to use home help services. Shiba et al. [26] noted that household income is an indicator of social support (e.g., informal caregiving from family members), which lowincome beneficiaries tend to lack. We posited that beneficiaries from low-income households would have less family support than those from middle/high-income households. Despite this, low-income beneficiaries may still choose to restrict out-of-pocket payments for home help services, and therefore spend less on such services than middle/high-income beneficiaries. A previous study in the US similarly found that home help service 
Table 6 Association of household income with home-based rehabilitation service utilization and expenditures

\begin{tabular}{|c|c|c|c|c|c|c|c|c|}
\hline & \multicolumn{4}{|c|}{$\begin{array}{l}\text { First part: Home-based rehabilitation service } \\
\text { utilization }(n=3770)\end{array}$} & \multicolumn{4}{|c|}{$\begin{array}{l}\text { Second part: Home-based rehabilitation service } \\
\text { expenditures }(n=681)\end{array}$} \\
\hline & $\overline{O R}$ & $95 \% \mathrm{Cl}$ & & $P$ value & $\mathrm{RR}$ & $95 \% \mathrm{Cl}$ & & $P$ value \\
\hline \multicolumn{9}{|l|}{ Household income } \\
\hline Middle/high income & 1.000 & & & & 1.000 & & & \\
\hline Low income & 0.813 & 0.670 & 0.987 & 0.036 & 0.910 & 0.829 & 0.999 & 0.047 \\
\hline \multicolumn{9}{|l|}{ Age (years) } \\
\hline $62-71$ & 1.000 & & & & 1.000 & & & \\
\hline $72-81$ & 0.454 & 0.346 & 0.596 & $<0.001$ & 0.965 & 0.855 & 1.088 & 0.557 \\
\hline$\geq 82$ & 0.328 & 0.249 & 0.433 & $<0.001$ & 1.032 & 0.910 & 1.170 & 0.662 \\
\hline \multicolumn{9}{|l|}{ Sex } \\
\hline Male & 1.000 & & & & 1.000 & & & \\
\hline Female & 0.689 & 0.571 & 0.832 & $<0.001$ & 1.073 & 0.982 & 1.171 & 0.118 \\
\hline \multicolumn{9}{|l|}{ Dwelling } \\
\hline Detached house & 1.000 & & & & 1.000 & & & \\
\hline Multiple-unit housing & 0.632 & 0.500 & 0.800 & $<0.001$ & 0.948 & 0.846 & 1.063 & 0.362 \\
\hline \multicolumn{9}{|l|}{ Care needs level } \\
\hline Care needs level 1 & 1.000 & & & & 1.000 & & & \\
\hline Care needs level 2 & 1.009 & 0.789 & 1.292 & 0.941 & 1.198 & 1.065 & 1.343 & 0.002 \\
\hline Care needs level 3 & 1.058 & 0.783 & 1.429 & 0.716 & 1.537 & 1.337 & 1.766 & $<0.001$ \\
\hline Care needs level 4 & 0.775 & 0.533 & 1.125 & 0.180 & 1.385 & 1.165 & 1.651 & $<0.001$ \\
\hline Care needs level 5 & 1.124 & 0.700 & 1.804 & 0.628 & 1.416 & 1.132 & 1.772 & 0.002 \\
\hline \multicolumn{9}{|l|}{ Physical function } \\
\hline Independent (Independent and Level J) & 1.000 & & & & 1.000 & & & \\
\hline Mild (Level A) & 1.360 & 0.974 & 1.897 & 0.071 & 1.208 & 1.030 & 1.415 & 0.020 \\
\hline Moderate (Level B) & 1.619 & 1.096 & 2.391 & 0.016 & 1.188 & 0.988 & 1.429 & 0.067 \\
\hline Severe (Level C) & 1.982 & 1.182 & 3.321 & 0.009 & 1.245 & 0.970 & 1.598 & 0.086 \\
\hline \multicolumn{9}{|l|}{ Cognitive function } \\
\hline Independent (Independent and Rank I) & 1.000 & & & & 1.000 & & & \\
\hline Mild (Rank II) & 0.557 & 0.448 & 0.692 & $<0.001$ & 1.084 & 0.977 & 1.202 & 0.128 \\
\hline Moderate (Rank III) & 0.476 & 0.366 & 0.618 & $<0.001$ & 1.100 & 0.970 & 1.247 & 0.137 \\
\hline Severe (Rank IV and Rank M) & 0.383 & 0.264 & 0.554 & $<0.001$ & 0.850 & 0.711 & 1.016 & 0.075 \\
\hline \multicolumn{9}{|l|}{ Chronic diseases } \\
\hline \multicolumn{9}{|l|}{ Cerebrovascular disease } \\
\hline Absent & 1.000 & & & & 1.000 & & & \\
\hline Present & 1.707 & 1.427 & 2.042 & $<0.001$ & 1.101 & 1.011 & 1.199 & 0.027 \\
\hline \multicolumn{9}{|l|}{ Joint disorders } \\
\hline Absent & 1.000 & & & & 1.000 & & & \\
\hline Present & 1.643 & 1.358 & 1.988 & $<0.001$ & 0.923 & 0.842 & 1.011 & 0.086 \\
\hline \multicolumn{9}{|l|}{ Heart disease } \\
\hline Absent & 1.000 & & & & 1.000 & & & \\
\hline Present & 0.955 & 0.788 & 1.156 & 0.633 & 0.970 & 0.886 & 1.063 & 0.515 \\
\hline \multicolumn{9}{|l|}{ Parkinson's disease } \\
\hline Absent & 1.000 & & & & 1.000 & & & \\
\hline Present & 2.243 & 1.641 & 3.064 & $<0.001$ & 0.938 & 0.815 & 1.079 & 0.372 \\
\hline
\end{tabular}


Table 6 Association of household income with home-based rehabilitation service utilization and expenditures (Continued)

\begin{tabular}{|c|c|c|c|c|c|c|c|c|}
\hline & \multicolumn{4}{|c|}{$\begin{array}{l}\text { First part: Home-based rehabilitation service } \\
\text { utilization }(n=3770)\end{array}$} & \multicolumn{4}{|c|}{$\begin{array}{l}\text { Second part: Home-based rehabilitation service } \\
\text { expenditures }(n=681)\end{array}$} \\
\hline & $\overline{\mathrm{OR}}$ & $95 \% \mathrm{Cl}$ & & $P$ value & $\mathrm{RR}$ & $95 \% \mathrm{Cl}$ & & $P$ value \\
\hline \multicolumn{9}{|l|}{ Long-term care service use } \\
\hline \multicolumn{9}{|l|}{ Home help services } \\
\hline Non-use & 1.000 & & & & 1.000 & & & \\
\hline Use & 0.877 & 0.721 & 1.067 & 0.189 & 0.922 & 0.838 & 1.014 & 0.095 \\
\hline \multicolumn{9}{|l|}{ Home-visit nursing } \\
\hline Non-use & 1.000 & & & & 1.000 & & & \\
\hline Use & 1.994 & 1.518 & 2.621 & $<0.001$ & 0.946 & 0.824 & 1.085 & 0.427 \\
\hline \multicolumn{9}{|l|}{ Type of home-based rehabilitation services } \\
\hline $\begin{array}{l}\text { Home visit rehabilitation from medical facilities } \\
\text { or nursing homes }\end{array}$ & & & & & 1.000 & & & \\
\hline $\begin{array}{l}\text { Home visit rehabilitation from visiting nurse } \\
\text { agencies }\end{array}$ & & & & & 0.939 & 0.799 & 1.104 & 0.446 \\
\hline Day care services & & & & & 2.524 & 2.172 & 2.934 & $<0.001$ \\
\hline \multicolumn{9}{|l|}{ Medical expenditures } \\
\hline Lower group & 1.000 & & & & 1.000 & & & \\
\hline Middle group & 0.782 & 0.632 & 0.968 & 0.024 & 0.970 & 0.877 & 1.072 & 0.548 \\
\hline Higher group & 0.590 & 0.470 & 0.741 & $<0.001$ & 0.922 & 0.825 & 1.031 & 0.154 \\
\hline C statistic & 0.714 & \multicolumn{7}{|c|}{$(0.693-0.735)$} \\
\hline
\end{tabular}

First part: multivariate logistic regression analysis; Second part: generalized linear model for gamma-distributed data with a log-link function OR Odds ratio; RR Risk ratio; 95\% Cl 95\% Confidence interval

expenditures were lower for older adults with low income than those with higher income [27]. Our findings suggest that low-income subjects may have reduced their home help service utilization to lighten their out-ofpocket payments. Conversely, middle/high-income subjects may have utilized more home help services than their upper expenditure limits allow. The burden of outof-pocket payments for low-income beneficiaries may influence their choice of home-based rehabilitation and home help services. To lighten this burden and improve access to these services, it may be important to examine ways to decrease the financial burden of low-income beneficiaries.

\section{Strengths and limitations}

The strengths of this study are as follows: First, this study focused on major LTC services in Japan by linking medical and LTC insurance claims data, and included medical expenditures in the analysis. Second, we also examined home-based rehabilitation services, which are provided under the LTC insurance system and constitute a distinctive component of Japan's LTC services. These services are generally provided as a medical service in Europe [28-30], and are often unavailable in Asian countries [31, 32].

Our findings should be interpreted with consideration to three limitations. First, this study used secondary data without variables that may affect household income and the utilization of home care services. In particular, household income is dependent on the number of household members, and the presence of family caregivers could affect the decision to use home help services. Moreover, we used household income due to its availability, but a beneficiary's total assets or savings would be more appropriate indicators of his/her economic status [33]. Additionally, we could not take into account the system in which municipalities and medical insurers take over payments for medical and LTC services in cases where a family's medical and LTC expenditures in the previous year exceed a governmentdesignated limit [34]. This system would help beneficiaries select medical and LTC services according to their needs, but we could not estimate its effects due to the lack of total expenditure data for each's beneficiary's household. However, this is still an ancillary system and the number of users would be relatively low. Second, this study used a cross-sectional design, which precludes any inferences on causal relationships. Although LTC service utilization is unlikely to lower a beneficiary's household income, out-of-pocket payments may affect his/her household income in the low-income group. Finally, the study was conducted in one city (municipality) in a suburban area, and therefore has limited generalizability to other municipalities and LTC 
Table 7 Association of household income with home help service utilization and expenditures

\begin{tabular}{|c|c|c|c|c|c|c|c|c|}
\hline & \multicolumn{4}{|c|}{$\begin{array}{l}\text { First part: Home help service } \\
\text { utilization }(n=3770)\end{array}$} & \multicolumn{4}{|c|}{$\begin{array}{l}\text { Second part: Home help service } \\
\text { expenditures }(n=1163)\end{array}$} \\
\hline & $\overline{\mathrm{OR}}$ & $95 \% \mathrm{Cl}$ & & $P$ value & $\overline{\mathrm{RR}}$ & $95 \% \mathrm{Cl}$ & & $P$ value \\
\hline \multicolumn{9}{|l|}{ Household income } \\
\hline Middle/high income & 1.000 & & & & 1.000 & & & \\
\hline Low income & 1.432 & 1.232 & 1.664 & $<0.001$ & 0.888 & 0.799 & 0.986 & 0.026 \\
\hline \multicolumn{9}{|l|}{ Age (years) } \\
\hline $62-71$ & 1.000 & & & & 1.000 & & & \\
\hline $72-81$ & 1.214 & 0.933 & 1.581 & 0.149 & 1.005 & 0.838 & 1.205 & 0.960 \\
\hline$\geq 82$ & 1.080 & 0.829 & 1.407 & 0.567 & 1.229 & 1.025 & 1.475 & 0.026 \\
\hline \multicolumn{9}{|l|}{ Sex } \\
\hline Male & 1.000 & & & & 1.000 & & & \\
\hline Female & 1.112 & 0.946 & 1.308 & 0.199 & 1.166 & 1.042 & 1.306 & 0.008 \\
\hline \multicolumn{9}{|l|}{ Dwelling } \\
\hline Detached house & 1.000 & & & & 1.000 & & & \\
\hline Multiple-unit housing & 1.443 & 1.220 & 1.706 & $<0.001$ & 1.238 & 1.107 & 1.384 & $<0.001$ \\
\hline \multicolumn{9}{|l|}{ Care needs level } \\
\hline Care needs level 1 & 1.000 & & & & 1.000 & & & \\
\hline Care needs level 2 & 0.930 & 0.758 & 1.140 & 0.483 & 1.232 & 1.070 & 1.419 & 0.004 \\
\hline Care needs level 3 & 0.930 & 0.724 & 1.194 & 0.570 & 2.075 & 1.743 & 2.469 & $<0.001$ \\
\hline Care needs level 4 & 1.260 & 0.941 & 1.688 & 0.121 & 2.615 & 2.132 & 3.209 & $<0.001$ \\
\hline Care needs level 5 & 1.404 & 0.964 & 2.044 & 0.077 & 3.218 & 2.504 & 4.136 & $<0.001$ \\
\hline
\end{tabular}

\section{Physical function}

Independent (Independent and Level J)

1.000

Mild (Level A)

Moderate (Level B)

Severe (Level C)

\section{Cognitive function}

Independent (Independent and Rank I)

Mild (Rank II)

Moderate (Rank III)

Severe (Rank IV and Rank M)

\section{Chronic diseases}

Cerebrovascular disease

Absent
Present
Joint disorders
Absent
Present
Heart disease
Absent
Present
Parkinson's disease
Absent
Present

\subsection{0}

0.949

0.818

1.102

0.494

1.000

1.170

1.005

1.362

0.043

1.000

1.024

0.877

1.195

0.763

1.000

1.204
0.905
1.000

0.955

0.862

1.058

0.375

1.000

0.919

0.828

1.020

0.113

1.000

0.973

0.876

1.081

0.609

1.000

1.127
0.929

1.366

0.225 
Table 7 Association of household income with home help service utilization and expenditures (Continued)

\begin{tabular}{|c|c|c|c|c|c|c|c|c|}
\hline & \multicolumn{4}{|c|}{$\begin{array}{l}\text { First part: Home help service } \\
\text { utilization }(n=3770)\end{array}$} & \multicolumn{4}{|c|}{$\begin{array}{l}\text { Second part: Home help service } \\
\text { expenditures }(n=1163)\end{array}$} \\
\hline & $\overline{\mathrm{OR}}$ & \multicolumn{2}{|c|}{$95 \% \mathrm{Cl}$} & $P$ value & $\overline{\mathrm{RR}}$ & \multicolumn{2}{|l|}{$95 \% \mathrm{Cl}$} & $P$ value \\
\hline \multicolumn{9}{|c|}{ Long-term care service use } \\
\hline \multicolumn{9}{|c|}{ Home-based rehabilitation services } \\
\hline Non-use & 1.000 & & & & 1.000 & & & \\
\hline Use & 0.873 & 0.718 & 1.061 & 0.171 & 0.764 & 0.667 & 0.876 & $<0.001$ \\
\hline \multicolumn{9}{|c|}{ Home-visit nursing } \\
\hline Non-use & 1.000 & & & & 1.000 & & & \\
\hline Use & 1.943 & 1.541 & 2.450 & $<0.001$ & 0.809 & 0.700 & 0.934 & 0.004 \\
\hline \multicolumn{9}{|c|}{ Type of home help service ${ }^{a}$} \\
\hline Single & & & & & 1.000 & & & \\
\hline Multiple & & & & & 1.621 & 1.306 & 2.012 & $<0.001$ \\
\hline \multicolumn{9}{|c|}{ Medical expenditures } \\
\hline Lower group & 1.000 & & & & 1.000 & & & \\
\hline Middle group & 1.014 & 0.848 & 1.212 & 0.877 & 1.066 & 0.941 & 1.208 & 0.315 \\
\hline Higher group & 1.206 & 1.004 & 1.448 & 0.045 & 1.274 & 1.124 & 1.444 & $<0.001$ \\
\hline C statistic & 0.632 & \multicolumn{3}{|c|}{$(0.613-0.651)$} & & & & \\
\hline
\end{tabular}

First part: multivariate logistic regression analysis; Second part: generalized linear model for gamma-distributed data with a log-link function

${ }^{a}$ Home help services comprise physical care, daily living support, and support for getting on and off transit vehicles; subjects who were provided only one of these services were categorized as using "single-type" services, and subjects who were provided two or more of these services were categorized as using "multiple-type" services

OR Odds ratio; $R R$ Risk ratio; $95 \%$ Cl 95\% Confidence interval

insurance beneficiaries aged 65-74 years who do not use community-based health insurance. Nevertheless, these findings could potentially be extrapolated to other municipalities with similar LTC resources and sociodemographic characteristics.

\section{Conclusion}

This study suggests that LTC insurance beneficiaries with low household income may forgo using homebased rehabilitation services. Moreover, they may choose to reduce the amount spent on home-based rehabilitation and home help services to minimize their out-ofpocket payments. Although older adults with low household income only need to pay $10 \%$ of expenditures as out-of-pocket payments, these copayments can accumulate to become a considerable burden. Policymakers need to further examine ways to decrease the financial burden of low-income beneficiaries and improve access to LTC services for low-income beneficiaries.

\section{Abbreviations}

LTC: Long-term care; ADL: Activities of daily living; ICD-10: International statistical classification of diseases and related health problems 10th revision

\section{Acknowledgements}

Not applicable.

\section{Authors' contributions}

RT, TI, SM conceptualized and designed the study. SY, KI, NT collected the data. RT, TI, SM, SH conducted the analysis and interpret the data. RT drafted the initial manuscript. TI, SM, SH, SY, KI, NT reviewed and revised the manuscript critically for important intellectual content. All authors approved the final manuscript as submitted.

\section{Funding}

This research did not receive any specific grant from funding agencies in the public, commercial, or not-for-profit sectors.

\section{Availability of data and materials}

All relevant data underlying this study are owned by Kashiwa city. There is a contract between Kashiwa city and the Institute of Gerontology, University of Tokyo. The contract stipulates the following; Kashiwa city does not allow the authors to use the data for any purpose other than this study or to provide it to anyone other than the study members without permission from Kashiwa city. Researchers interested in the data used here should contact the author, Dr. Ishizaki.

\section{Ethics approval and consent to participate}

The study protocol was approved by the Ethics Committee of Tokyo Metropolitan Institute of Gerontology (Approval No. 28; October 16, 2015). The committee waived the need for informed consent due to the use of anonymized claims data.

\section{Consent for publication}

Not applicable.

\section{Competing interests}

The authors declare that they have no competing interests.

\section{Author details}

${ }^{1}$ Human Care Research Team, Tokyo Metropolitan Institute of Gerontology, 35-2 Sakae-cho, Itabashi-ku, Tokyo 173-0015, Japan. ²Dia Foundation for Research on Ageing Societies, Tokyo, Japan. ${ }^{3}$ Research Department, Institute for Health Economics and Policy, Association for Health Economics Research and Social Insurance and Welfare, Tokyo, Japan. ${ }^{4}$ Health Services Research \& Development Center, University of Tsukuba, Ibaraki, Japan. ${ }^{5}$ Institute of Gerontology, University of Tokyo, Tokyo, Japan. ${ }^{6}$ Department of Health Policy and Management, School of Medicine, Keio University, Tokyo, Japan. 
${ }^{7}$ Institute for Future Initiatives, The University of Tokyo, Ibaraki, Japan. ${ }^{8}$ Department of Health Services Research, Faculty of Medicine, University of Tsukuba, Ibaraki, Japan.

Received: 13 February 2020 Accepted: 12 August 2020

Published online: 28 August 2020

\section{References}

1. Colombo F, Llena-Nozal A, Mercier J, Tjadens F. Help Wanted?: Providing and Paying for Long-Term Care: OECD Publishing; 2011. [cited 2018 Jul 18]. (OECD Health Policy Studies). Available from: http://dx.doi.org/10.1787/ 9789264097759-en.

2. Cabinet Office Government of Japan. Annual Report on the Aging Society 2018 [Kourei syakai hakusyo 2018]Chapter1 [Internet]. Cabinet office Government of Japan. 2018 [cited 2019 Feb 27]. Available from: https:// www8.cao.go.jp/kourei/whitepaper/w-2018/html/gaiyou/s1_1.html.

3. Cabinet Office Government of Japan. Annual Report on the Aging Society2018 [Kourei syakai hakusyo 2018]Chapter2 [Internet]. Cabinet office Government of Japan. 2018 [cited 2019 Feb 27]. Available from: https:// www8.cao.go.jp/kourei/whitepaper/w-2018/html/zenbun/s1_2_2.html.

4. Hamada S, Takahashi H, Sakata N, Jeon B, Mori T, lijima K, et al. Household income relationship with health services utilization and healthcare expenditures in people aged 75 years or older in japan: a population-based study using medical and long-term care insurance claims data. J Epidemiol. 2019;29(10):377-83.

5. Saito M, Fujita K, Hirano T, Okuda Y. Stability and change in the cost of care services due to premiums for longterm care insurance : from the data of individually provided care benefits in a specific municipality during two years. Q Soc Secur Res. 2011;47(3):293-303 [cited 2018 Apr 4] Available from: http://www.ipss.go.jp/syoushika/bunken/data/pdf/19613908.pdf.

6. Sugisawa H, Fukaya T, Sugihara Y, Ishikawa H, Nakatani Y, Kim H-K. Factors related to under-utilization of in-home services under the long term insurance system (in Japanese). Jpn J Public Heal. 2002;49(5):425-36 [cited 2018 Apr 4] Available from: https:/www.jstage.jst.go.jp/article/jph/49/5/49_425/_article/-char/ja/.

7. Tsutsui T, Muramatsu N. Care-needs certification in the long-term care insurance system of Japan. J Am Geriatr Soc. 2005;53(3):522-527. [cited 2018 Dec 1] Available from: http://doi.wiley.com/https://doi.org/10.1111/j.15325415.2005.53175.x

8. Kashiwagi M, Tamiya N, Sato M, Yano E. Factors associated with the use of home-visit nursing services covered by the long-term care insurance in rural Japan: a cross-sectional study. BMC Geriatr. 2013;13(1):1. [cited 2018 Mar 28] Available from: http://bmcgeriatr.biomedcentral.com/articles/https://doi.org/ 10.1186/1471-2318-13-1.

9. Cook RJ, Berg K, Lee K-A, Poss JW, Hirdes JP, Stolee P. Rehabilitation in home care is associated with functional improvement and preferred discharge. Arch Phys Med Rehabil. 2013;94(6):1038-47 [cited 2019 Oct 30] Available from: http://www.ncbi.nlm.nih.gov/pubmed/23385108.

10. Chi N-F, Huang Y-C, Chiu H-Y, Chang H-J, Huang H-C. Systematic review and meta-analysis of home-based rehabilitation on improving physical function among home-dwelling patients with a stroke. Arch Phys Med Rehabil. 2020;101(2):359-73.

11. Maruta M, Tabira T, Makizako H, Sagari A, Miyata H, Yoshimitsu K, et al. Impact of outpatient rehabilitation service in preventing the deterioration of the care-needs level among japanese older adults availing long-term care insurance: a propensity score matched retrospective study. Int J Environ Res Public Health. 2019;16(7):1292 [cited 2019 Oct 28] Available from: http://www.ncbi.nlm.nih.gov/pubmed/30974921

12. Ministry of Health Labour and Welfare. Revision for each Long-term care services in 2018 [in Japanese] [Internet]. 2018p. 4. [cited 2020 Jun 10] Available from: https://www.mhlw.go.jp/file/06-Seisakujouhou-12300000Roukenkyoku/0000196994.pdf.

13. Kashiwa city. Population vision in Kashiwa city [Kashiwashi jinkou bijon]. [Internet]. 2016. p. 1-70. [cited 2019 Oct 28] Available from: http://www.city. kashiwa.lg.jp/soshiki/020100/p034603_d/fil/kashiwashi_jinkovision.pdf.

14. Kawagoe S, Tsuda T, Doi H. Study on the factors determining home death of patients during home care: A historical cohort study at a home care support clinic. Geriatr Gerontol Int. 2013;13(4):874-80 [cited 2019 Oct 29] Available from: http://www.ncbi.nlm.nih.gov/pubmed/23279052.

15. Okamoto E. Public Health of Japan 2017. Tokyo: Japan Public Health Association; 2017. Available at: http://www.jpha.or.jp/sub/pdf/PHJ2017_web. pdf. Accessed 15 Aug 2019.
16. Ikegami N, Yoo B-K, Hashimoto H, Matsumoto M, Ogata H, Babazono A, et al. Japanese universal health coverage: evolution, achievements, and challenges. Lancet. 2011;378(9796):1106-15 [cited 2019 Jan 30] Available from: http://www.ncbi.nlm.nih.gov/pubmed/21885107.

17. Bank of Japan. Tables of key time series statistics [internet]. 2020 [cited 2020 Jan 15]. Available from: https://wnw.stat-search.boj.or.jp/ssi/mtshtml/fm08_m_1.html.

18. Ministry of Health Labour and Welfare. White paper on Health, Labour, and Welfare in 2017 [in Japanese] [Internet]. 2018 [cited 2020 Jun 17]. Available from: https://www.mhlw.go.jp/wp/hakusyo/kousei/17/dl/all.pdf.

19. Ouchi Y, Rakugi $H$, Arai H, Akishita M, Ito H, Toba K, et al. Redefining the elderly as aged 75 years and older: proposal from the joint Committee of Japan Gerontological Society and the Japan geriatrics society. Geriatr Gerontol Int. 2017;17(7):1045-7.

20. Ministry of Health Labour and Welfare. Comprehensive Survey of Living Conditions in 2016 [Heisei28nen Kokumin seikatsu kiso tyousa] [lnternet]. 2016 [cited 2020 Apr 29]. Available from: http://www.mhlw.go.jp/toukei/ saikin/hw/k-tyosa/k-tyosa16/dl/16.pdf.

21. Mitsutake S, Ishizaki T, Teramoto C, Shimizu S, Ito H. Patterns of cooccurrence of chronic disease among older adults in Tokyo, Japan. Prev Chronic Dis. 2019;16:E11 [cited 2019 may 15] Available from: http://www. ncbi.nlm.nih.gov/pubmed/30703000.

22. Duan N, Manning WG, Morris CN, Newhouse JP. A comparison of alternative models for the demand for medical care. J Bus Econ Stat. 1983; (2):115-126. [cited 2018 May 9] Available from: http://www.tandfonline.com/doi/abs/ https://doi.org/10.1080/07350015.1983.10509330.

23. Diehr $P$, Yanez D, Ash A, Hornbrook M, Lin DY. Methods for analyzing health care utilization and costs. Annu Rev Public Health. 1999;20(1):125-144. [cited 2020 Jul 2] Available from: http://www.annualreviews.org/doi/https://doi. org/10.1146/annurev.publhealth.20.1.125.

24. Pol M van der, Irvine A. Time preferences for health [Internet]. Oxford Resaerch Encyclopedia of Economics and Finance. Oxford: Oxford University Press, [Online textbook]; 2018. Available from: https://oxfordre.com/ economics/abstract/https://doi.org/10.1093/acrefore/9780190625979.001. 0001/acrefore-9780190625979-e-87?rskey=LOh7iY\&result=1.

25. Lawrance EC. Poverty and the rate of time preference: evidence from panel data. J Polit Econ. 1991;99(1):54-77. [cited 2019 Apr 24] Available from: https://www.journals.uchicago edu/doi/https://doi.org/10.1086/261740.

26. Shiba K, Kondo N, Kondo K. Informal and formal social support and caregiver burden: the AGES caregiver survey. J Epidemiol. 2016;26(12):622-8 [cited 2019 Jan 30] Available from: https://www.jstage.jst.go.jp/article/ jea/26/12/26_JE20150263/_article.

27. Bass DM, Noelker LS. The influence of family caregivers on elder's use of inhome services: an expanded conceptual framework. J Health Soc Behav. 1987;28(2):184 [cited 2018 Dec 1] Available from: http://www.jstor.org/ stable/2137131?origin=crossref.

28. Tachibana S. The current situation of home rehabilitation in developed countries2; home visit rehabilitation in France. (in Japanese). Homecare Rehabil. 2014:4(2):123-7.

29. Manabe A. The current situation of home rehabilitation in developed countries1; home visit rehabilitation in Illinois state, USA.(in Japanese). Homecare Rehabil. 2014;4(2):117-21.

30. Yamaguchi M. Reports of the clinical site of Sweden - welfare developed countries seen by Japanese physical therapist - (in Japanese). Tokyo, Japan: Shinhyoron Publishing Inc.; 2006.

31. Suda Y, Hiraoka K, Morikawa M. Elderly care in East Asia - county, community, and family - (in Japanese). Tokyo, Japan: Toshindo Publishing Co., Itd.; 2018. p. 354-5.

32. Yamamoto J. Current education of community rehabilitation in Asian physical therapy association (in Japanese). Homecare Rehabil. 2014;4(2):129-30.

33. Allin S, Masseria C, Mossialos E. Measuring socioeconomic differences in use of health care services by wealth versus by income. Am J Public Health. 2009;99(10):1849-1855. [cited 2019 Oct 29] Available from: http://ajph. aphapublications.org/doi/https://doi.org/10.2105/AJPH.2008.141499.

34. Ministry of Health Labour and Welfare. The system for expensive medical and long-term care expenditure [Internet]. 2016 [cited 2019 May 15]. Available from: https://www.mhlw.go.jp/file/05-Shingikai-12601000Seisakutoukatsukan-Sanjikanshitsu_Shakaihoshoutantou/0000143276.pdf.

\section{Publisher's Note}

Springer Nature remains neutral with regard to jurisdictional claims in published maps and institutional affiliations. 